
університету. - Серія "Регіональна економіка". - Випуск 15 (59). - Редкол.: відп. ред. д.е.н., професор Л.Л. Ковальська. - Луиьк: ІВВ Луиького НТУ, 2018. - 292 с.

УДК 336.7:339.7

Корецька Н.І., к.е.н., доцент,

Олійник С.Б.

Луцький національний технічний університет

\title{
РЕГІОНАЛЬНІ ОСОБЛИВОСТІ ІНВЕСТИЦІЙНОЇ АКТИВНОСТІ В СФЕРІ СІЛЬСЬКОГО ГОСПОДАРСТВА
}

Досліджено рівень інвестиційної активності в сільському господарстві регіонів України, встановлено значну різницю в обсягах залучення інвестиційних вкладень, що істотно впливає на фінансові результати даного виду економічної діяльності в регіонах України. Обгрунтовано необхідність покращення інвестиційного клімату та нарощення інвестицій у галузь сільського господарства в усіх регіонах України.

Ключові слова: інвестиції, сільське господарство, сільськогосподарські угіддя, сільськогосподарський працівник, інвестиційна активність, регіон.

Koretskya N., Oliynyk S.

\section{REGIONAL FEATURES OF INVESTMENT ACTIVITY IN THE FIELD OF AGRICULTURE}

The development of agriculture, ensuring its competitiveness in the domestic and foreign markets requires the creation of a favorable investment climate and the provision of investment activity in the agricultural sector in all regions of Ukraine.

In each country, agriculture is a vital part of the national economy (more than $80 \%$ of the consumption fund is formed at the expense of agricultural products), and attracting investment in this type of economic activity in the medium and long term is a prerequisite. 
Економічні науки: збірник наукових праџь Луцького національного технічного університету. - Серія "Регіональна економіка". - Випуск 15 (59). - Редкол.: відп. ред. д.е.н., професор Л.Л. Ковальська. - Луцьк: ІВВ Луцького НТУ, 2018. - 292 с.

The article analyzes the actual level of investment activity of agriculture in the regions of Ukraine, which is largely characterized by the following indicators: investments per hectare of agricultural land and 1 employee in the industry.

It has been established that on average in Ukraine in 2017 per capita agricultural land was invested 1597,0 UAH of investments, which is 2 times more than in 2015.

In total, the volume of attracted investments per hectare of agricultural land by regions is significantly different. So, in 2017, the leader among the regions for this indicator was the Kiev region and Kiev, while the smallest investments per hectare of agricultural land fell to the Transcarpathian region. In general, in 2017, the largest volume of investments (except Kyiv oblast and Kyiv) was involved in Ternopil, Vinnytsya, Poltava and Cherkasy regions, and the smallest (except for the Transcarpathian region) were Chernivtsi, Lugansk, Donetsk and Lviv regions.

The largest amount of investments per one employee in 2017 was involved in Chernihiv, Zhytomyr, Rivne and Ternopil regions, and the smallest - in Zakarpattya, Chernivtsi, Donetsk, Cherkasy and Luhansk regions.

According to the integrated assessment, it was found that the regions with a high level of attraced investments included the Kyiv region and the cities of Kyiv, Zaporozhye and Chernihiv regions; to the regions with an average level - V innytsa, Dnipropetrovsk, Zhytomyr, Kirovograd, Poltava, Rivne, Sumy, Ternopil, Kharkiv, Kherson, Khmelnytsky, Cherkassk, and to regions with low - Volyn, Donetsk, Zakarpattia, Ivano-Frankivsk, Lugansk, Lviv, Nikolaev, Odessa and Chernivtsi.

It is proved that such a difference in the levels of investment activity of the regions of Ukraine is a result of, first of all, differences in the levels of their socio-economic development and state and regional policy, which requires the achievement of the following strategic goals: full provision of agricultural development needs in investment resources; ensuring the growth of investment opportunities of agricultural producers; expansion of agricultural financing in order to increase its investment attractiveness.

Key words: investment, agriculture, agricultural land, agricultural worker, investment activity, region.

Корецкая Н.И., Олийнык С.Б.

\section{РЕГИОНАЛЬНЫЕ ОСОБЕННОСТИ ИНВЕСТИЦИОННОЙ АКТИВНОСТИ В СФЕРЕ СЕЛЬСКОГО ХОЗЯЙСТВА}

Исследован уровень инвестиционной активности в сельском хозяйстве регионов Украины, установлено значительную разницу в объемах привлечения инвестиционных вложений, что существенно влияет на финансовые результаты данного вида экономической деятельности в регионах Украины. Обоснована необходимость улучшения инвестиционного климата и наращивание инвестиций в отрасль сельского хозяйства во всех регионах Украины. 
Економічні науки: збірник наукових праџь Луцького національного технічного університету. - Серія "Регіональна економіка". - Випуск 15 (59). - Редкол.: відп. ред. д.е.н., професор Л.Л. Ковальська. - Луцьк: ІВВ Луцького НТУ, 2018. - 292 с.

Ключевые слова: инвестиции, сельское хозяйство, сельскохозяйственные угодья, сельскохозяйственный работник, инвестиционная активность, регион.

\section{Постанова проблеми у загальному вигляді та її зв'язок 3} важливими науковими і практичними завданнями. Формування стратегії забезпечення ефективності інвестиційного розвитку національної економіки України в розрізі регіонів і видів економічної діяльності $є$ важливим завданням, оскільки від цього залежить не лише стан розвитку країни, але й іiі економічне зростання. Проте, в Україні ряд факторів (в першу чергу, політична невизначеність, несприятливе законодавство, низький рівень платоспроможності споживачів, високий рівень податків, нестача оборотних коштів, труднощі 3 отриманням довгострокових кредитів, корупція тощо) негативно впливає на процес залучення інвестицій у види економічної діяльності в регіонах України, що перешкоджає забезпеченню їх інвестиційної привабливості.

В кожній країні сільське господарство є життєво необхідною галуззю національної економіки (понад 80\% фонду споживання формується за рахунок сільськогосподарської продукції [1]) i залучення інвестицій саме в даний вид економічної діяльності на середньо- і довгострокову перспективу є необхідною умовою. Саме інвестиції при ефективному їх використанні дозволять забезпечити необхідні масштаби і темпи структурної перебудови сільського господарства на регіональному і державному рівнях. Тому дана проблема є актуальною і потребує комплексного дослідження.

Аналіз останніх досліджень, у яких започатковано вирішення проблеми. Інвестиційні процеси досліджували зарубіжні та українські учені, зокрема, Дж. Кейнс, Л. Роббінс, Дж. Сакс, М.Фрідмен, Ф.Хайєк, Д. Хікс, О.Амош, І. Бланк, А. Буряк, А. Гайдуцький, В. Голіков, І. Вініченко, М. Долішній, О. Дудчик, М. Згуровський, М. Зубець, Ф. Іванов, Ю. Кашуба, Б. Кваснюк, М. Кісіль, Н. Малік, Л. Мармуль, М. Прокопенко, О. Покатаєва, О. Редькін, С. Румянцева, П. Саблук, В. Ситник, Н. Танклевська, Б. Твіст, В. Точилін, Р. Фатхутдінов, Л. Федулова, Ф. Хедоурі, Б. Холод, Д. Черваньов, О. Чубукова, М. Чумаченко, Я.Янишин, та ін. Проблемі інвестиційної 
Економічні науки: збірник наукових праџь Луцького національного технічного університету. - Серія "Регіональна економіка". - Випуск 15 (59). - Редкол.: відп. ред. д.е.н., професор Л.Л. Ковальська. - Луиьк: ІВВ Луиького НТУ, 2018. - 292 с.

підтримки сільського господарства присвячені наукові праці М. Дем'яненка, А. Діброви, О. Бородіної, М. Латиніна, Ю. Лупенка, О. Могильного, Т. Осташко, Б. Пасхавера, П. Саблука, Л. Тулуша та ін. Однак, не дивлячись на значний доробок наукових праць, присвячених даній стратегічній проблемі, більш детального дослідження потребують економічні механізми здійснення інвестування в сільське господарство регіонів.

Цілі статті: дослідження регіональних особливостей інвестиційної активності в сільському господарстві в регіонах України.

Викладення основного матеріалу дослідження 3 повним обгрунтуванням отриманих наукових результатів. Сільськогосподарська галузь в Україні $є$ важливим сектором економіки країни, частка якої становить $21 \%$ загального обсягу валової доданої вартості [1].

Нині в Україні зберігається тенденція зростання інвестицій в сільське господарство. За підсумками 2017 року у сільському господарстві освоєно 57,0 млрд грн капітальних інвестицій, що на $31,2 \%$ більше, ніж у 2016 році. Загалом частка капітальних інвестицій у сільське господарство склала $14 \%$ від загального обсягу.

I, не дивлячись на те, що сільське господарство протягом останніх років за темпами і стабільністю зростання інвестицій залишається лідером серед усіх видів економічної діяльності в Україні (у 2017 році приріст вкладень в дану галузь склав 58\% [1]), необхідно і надалі здійснювати пошук шляхів щодо збільшення обсягів інвестицій в розвиток сільського господарства. Але все це вимагає здійснення оцінки ефективності залучення інвестицій в сільське господарство регіонів України.

Наявність інвестиційних ризиків у сільському господарстві та інвестиційна політика не повинні бути спрямовані лише на збільшення інвестицій у сільське господарство, але i на забезпечення стійкого характеру інвестицій. Розглянемо динаміку капітальних інвестицій у сільське господарство України (табл. 1). 
Економічні науки: збірник наукових праџь Луцького національного технічного університету. - Серія "Регіональна економіка". - Випуск 15 (59). - Редкол.: відп. ред. д.е.н., професор Л.Л. Ковальська. - Луцьк: ІВВ Луиького НТУ, 2018. - 292 с.

Таблиця 1

Динаміка капітальних інвестицій

у сільське господарство України протягом 2010-2017 років

\begin{tabular}{|c|c|c|c|}
\hline \multirow[b]{2}{*}{ Рік } & \multicolumn{2}{|c|}{$\begin{array}{c}\text { Освоєно (використано) капітальних інвестицій, } \\
\text { у фактичних цінах, в млн. грн. }\end{array}$} & \multirow{2}{*}{$\begin{array}{c}\text { у\% } \\
\text { до } \\
\text { загального } \\
\text { обсягу }\end{array}$} \\
\hline & усього & $\begin{array}{c}\text { сільське господарство, мисливство } \\
\text { та надання пов'язаними із ними } \\
\text { послуг }\end{array}$ & \\
\hline 2010 рік & 157617,0 & 8611,0 & 5,5 \\
\hline 2011 рік & 211549,1 & 13215,1 & 6,2 \\
\hline 2012 рік & 244214,6 & 15338,7 & 6,3 \\
\hline 2013 рік & 231322,6 & 15745,9 & 6,8 \\
\hline 2014 рік & 204061,7 & 16754,3 & 8,2 \\
\hline 2015 рік & 251154,3 & 27078,9 & 10,8 \\
\hline 2016 рік & 326163,7 & 44246,3 & 13,6 \\
\hline 2017 рік & 412812,7 & 56978,9 & 13,8 \\
\hline
\end{tabular}

Примітка. Розраховано на основі даних джерела: [1]

Дані таблиці 1 свідчать про поступове зростання капітальних інвестицій в сільське господарство України протягом 2010-2017 років, а отже про зростання популярності даної галузі на фоні загальної нестабільності залучення капітальних інвестицій в економіку країни. При цьому варто зазначити, що головним джерелом фінансування капітальних інвестицій в АПК України залишаються власні кошти підприємств та організацій і складають понад 76\% від загальної вартості.

На нашу думку, фактичний рівень інвестиційної активності сільського господарства регіону значною мірою характеризують наступні показники: обсяги вкладень на 1 га сільськогосподарських угідь (табл. 2) та на 1 працівника даної галузі (табл. 3).

Так, в середньому по Україні у 2017 році в розрахунку на 1 га сільськогосподарських угідь було вкладено 1597,0 грн інвестицій, що майже у 2 рази більше у порівнянні з 2015 роком. 
Економічні науки: збірник наукових праџь Луцького національного технічного університету. - Серія "Регіональна економіка". - Випуск 15 (59). - Редкол.: відп. ред. д.е.н., професор Л.Л. Ковальська. - Луиьк: ІВВ Луиького НТУ, 2018. - 292 с.

Таблиця 2

Рейтинг регіонів за обсягом залучених інвестицій на 1 га сільськогосподарських угідь за регіонами у 2017 році

\begin{tabular}{|c|c|c|c|c|c|}
\hline Регіон & $\begin{array}{c}\text { Обсяг } \\
\text { капітальних } \\
\text { інвестицій } \\
\text { млн. грн. }\end{array}$ & $\begin{array}{c}\text { Площа } \\
\text { сільсько- } \\
\text { господарських } \\
\text { угідь, млн. га }\end{array}$ & $\begin{array}{c}\text { Рівень } \\
\text { інвестиційної } \\
\text { активності } \\
\text { грн. / га }\end{array}$ & Рейтинг & $\begin{array}{c}\text { Нормування } \\
\text { показника }\end{array}$ \\
\hline Вінницька & 4576,2 & 2,0 & 2288,1 & 3 & 0,625 \\
\hline Волинська & 1109,0 & 1,0 & 1109,0 & 19 & 0,303 \\
\hline Дніпропетровська & 3864,5 & 2,5 & 1545,8 & 13 & 0,422 \\
\hline Донецька & 1313,0 & 2,0 & 656,5 & 21 & 0,179 \\
\hline Житомирська & 2622,6 & 1,5 & 1748,4 & 6 & 0,478 \\
\hline Закарпатська & 96,4 & 0,5 & 192,8 & 24 & 0,053 \\
\hline Запорізька & 2926,8 & 2,2 & 1330,4 & 16 & 0,975 \\
\hline $\begin{array}{c}\text { Івано- } \\
\text { Франківська }\end{array}$ & 794,2 & 0,6 & 1323,7 & 17 & 0,362 \\
\hline $\begin{array}{l}\text { Київська, } \\
\text { м. Київ }\end{array}$ & 6220,2 & 1,7 & 3658,9 & 1 & 1,000 \\
\hline Кіровоградська & 3431,1 & 2,0 & 1715,6 & 7 & 0,469 \\
\hline Луганська & 1190,6 & 1,9 & 626,6 & 22 & 0,171 \\
\hline Львівська & 1338,8 & 1,3 & 1029,8 & 20 & 0,281 \\
\hline Миколаївська & 2582,0 & 2,0 & 1291,0 & 18 & 0,353 \\
\hline Одеська & 3547,0 & 2,6 & 1364,2 & 15 & 0,373 \\
\hline Полтавська & 4760,2 & 2,2 & 2163,7 & 4 & 0,591 \\
\hline Рівненська & 1433,9 & 0,9 & 1593,2 & 11 & 0,435 \\
\hline Сумська & 2726,3 & 1,7 & 1603,7 & 10 & 0,438 \\
\hline Тернопільська & 2541,7 & 1,0 & 2541,7 & 2 & 0,695 \\
\hline Харківська & 3600,1 & 2,4 & 1500,0 & 14 & 0,410 \\
\hline Херсонська & 3183,6 & 2,0 & 1591,8 & 12 & 0,435 \\
\hline Хмельницька & 2704,4 & 1,6 & 1690,3 & 8 & 0,462 \\
\hline Черкаська & 3178,5 & 1,5 & 2119,0 & 5 & 0,579 \\
\hline Чернівецька & 284,6 & 0,5 & 569,2 & 23 & 0,156 \\
\hline Чернігівська & 3375,0 & 2,1 & 1607,1 & 9 & 0,439 \\
\hline Украӥна & 63400,7 & 39,7 & 1597,0 & - & - \\
\hline
\end{tabular}

Примітка. Розраховано на основі даних джерела: [2, с. 66]

Дані без урахування тимчасово окупованої території АР Крим, м. Севастополя

Загалом, як свідчать дані табл. 2, обсяги залучених інвестицій на 1 га сільськогосподарських угідь за регіонами суттєво відрізняються. Так, у 2017 році лідером серед регіонів за даним показником були Київська область та м. Київ, в той час як найменше інвестицій на 1 га сільськогосподарських угідь припало на Закарпатську область. Загалом у 2017 році найбільший обсяг інвестицій (крім Київської області та м. Києва) було залучено у 
Економічні науки: збірник наукових праиь Луиького національного технічного університету. - Серія "Регіональна економіка". - Випуск 15 (59). - Редкол.: відп. ред. д.е.н., професор Л.Л. Ковальська. - Луцьк: ІВВ Луиького НТУ, 2018. - 292 с.

Тернопільську, Вінницьку, Полтавську та Черкаську області, а найменший (крім Закарпатської області) - у Чернівецьку, Луганську, Донецьку та Львівську області.

Таблиця 3

Рейтинг регіонів за обсягом залучених інвестицій

на 1 працівника сільськогосподарської галузі

за регіонами у 2017 році

\begin{tabular}{|c|c|c|c|c|c|}
\hline Регіон & $\begin{array}{c}\text { Обсяг } \\
\text { капітальних } \\
\text { інвестицій } \\
\text { млн. грн. }\end{array}$ & $\begin{array}{c}\text { Чисельність } \\
\text { найманих } \\
\text { працівників, } \\
\text { млн. осіб }\end{array}$ & $\begin{array}{c}\text { Рівень } \\
\text { інвестиційної } \\
\text { активності } \\
\text { грн. / осіб }\end{array}$ & Рейтинг & $\begin{array}{c}\text { Нормування } \\
\text { показника }\end{array}$ \\
\hline Вінницька & 4576,2 & 0,039 & 117338,5 & 17 & 0,139 \\
\hline Волинська & 1109,0 & 0,008 & 138625,0 & 7 & 0,164 \\
\hline Дніпропетровська & 3864,5 & 0,032 & 120765,6 & 16 & 0,143 \\
\hline Донецька & 1313,0 & 0,016 & 82062,5 & 22 & 0,097 \\
\hline Житомирська & 2622,6 & 0,012 & 218550,0 & 2 & 0,259 \\
\hline Закарпатська & 96,4 & 0,002 & 48200,0 & 24 & 0,057 \\
\hline Запорізька & 2926,8 & 0,023 & 127252,2 & 11 & 0,151 \\
\hline $\begin{array}{c}\text { Івано- } \\
\text { Франківська }\end{array}$ & 794,2 & 0,007 & 113457,1 & 18 & 0,134 \\
\hline Київська, м. Київ & 6220,2 & 0,051 & 121964,7 & 15 & 0,145 \\
\hline Кіровоградська & 3431,1 & 0,027 & 127077,8 & 12 & 0,151 \\
\hline Луганська & 1190,6 & 0,011 & 108236,4 & 20 & 0,128 \\
\hline Львівська & 1338,8 & 0,008 & 167350,0 & 5 & 0,198 \\
\hline Миколаївська & 2582,0 & 0,02 & 129100,0 & 10 & 0,153 \\
\hline Одеська & 3547,0 & 0,028 & 126678,6 & 13 & 0,150 \\
\hline Полтавська & 4760,2 & 0,042 & 113338,1 & 19 & 0,134 \\
\hline Рівненська & 1433,9 & 0,007 & 204842,9 & 3 & 0,243 \\
\hline Сумська & 2726,3 & 0,02 & 136315,0 & 8 & 0,162 \\
\hline Тернопільська & 2541,7 & 0,013 & 195515,4 & 4 & 0,232 \\
\hline Харківська & 3600,1 & 0,027 & 133337,0 & 9 & 0,158 \\
\hline Херсонська & 3183,6 & 0,021 & 151600,0 & 6 & 0,180 \\
\hline Хмельницька & 2704,4 & 0,022 & 122927,3 & 14 & 0,146 \\
\hline Черкаська & 3178,5 & 0,033 & 96318,2 & 21 & 0,114 \\
\hline Чернівецька & 284,6 & 0,004 & 71150,0 & 23 & 0,084 \\
\hline Чернігівська & 3375,0 & 0,004 & 843750,0 & 1 & 1,000 \\
\hline Украӥна & 63400,7 & 0,477 & 132915,5 & - & - \\
\hline
\end{tabular}

Примітка. Розраховано на основі даних джерела: [2, с. 175]

Дані без урахування тимчасово окупованої території АР Крим,

м. Севастополя

Згідно 3 даними табл. 3, у 2017 році найбільший обсяг інвестицій у розрахунку на одного працівника було залучено у 

університету. - Серія "Регіональна економіка". - Випуск 15 (59). - Редкол.: відп. ред. д.е.н., професор Л.Л. Ковальська. - Луцьк: ІВВ Луиького НТУ, 2018. - 292 с.

Чернігівську, Житомирську, Рівненську та Тернопільську області, а найменший - у Закарпатську, Чернівецьку, Донецьку, Черкаську та Луганську області.

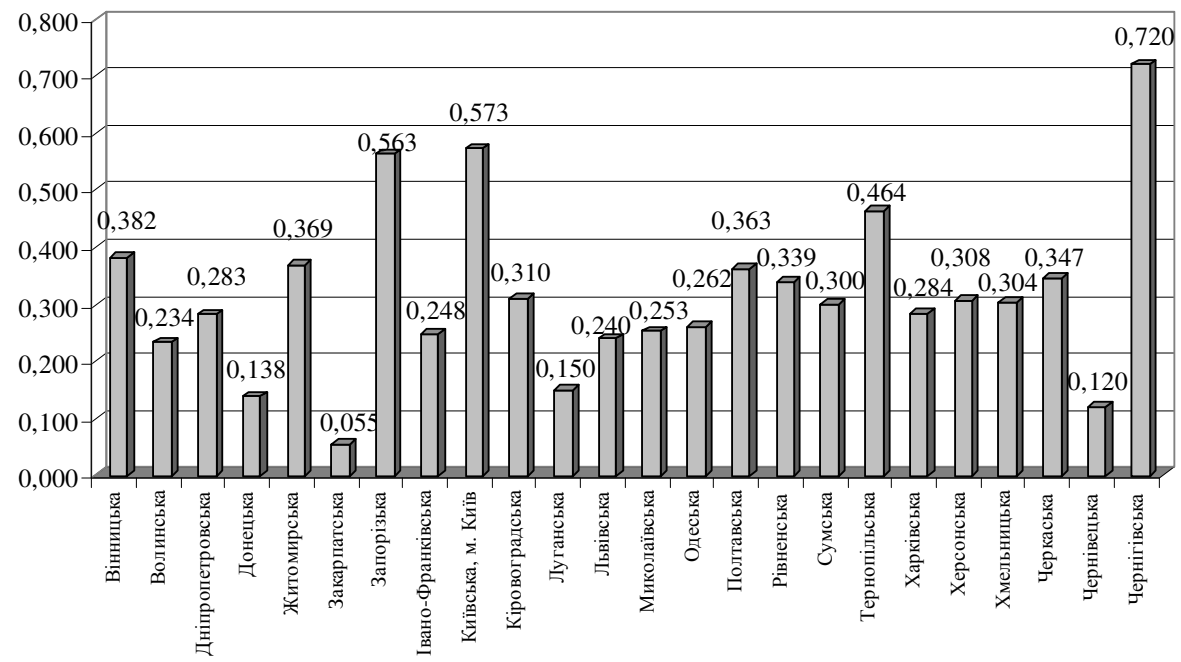

Рис. 1. Інтегральний показник інвестиційної активності у сфері сільського господарства регіонів України (2017 рік)

Примітка. Сформовано авторами

Згідно інтегрального показника до регіонів з високим рівнем залучення інвестицій увійшли Київська область і м. Київ, Запорізька та Чернігівська області; до регіонів з середнім рівнем - 12 регіонів (Вінницька, Дніпропетровська, Житомирська, Кіровоградська, Полтавська, Рівненська, Сумська, Тернопільська, Харківська, Херсонська, Хмельницька, Черкаська області), а до регіонів 3 низьким рівнем - Волинська, Донецька, Закарпатська, ІваноФранківська, Луганська, Львівська, Миколаївська, Одеська та Чернівецька області.

Вважаємо, що така різниця за рівнями інвестиційної активності регіонів України є наслідком передусім відмінностей у 
Економічні науки: збірник наукових праџь Луцького національного технічного університету. - Серія "Регіональна економіка". - Випуск 15 (59). - Редкол.: відп. ред. д.е.н., професор Л.Л. Ковальська. - Луцьк: ІВВ Луиького НТУ, 2018. - 292 с.

рівнях їх соціально-економічного розвитку і державної та регіональної політики.

Отже, не дивлячись на нестабільне політико-економічне становище країни, несприятливий інвестиційний клімат, відсутність обгрунтованої концепції економічного розвитку регіонів, сільське господарство залишається перспективною галуззю. Проте у більшість регіонів України залучаються незначні обсяги капітальних інвестицій, що не дозволяє підвищити рівень ефективності сільськогосподарського виробництва. Тому задля стимулювання припливу інвестицій в сільське господарство та активізації інвестиційної діяльності сільськогосподарських підприємств необхідно досягати наступних стратегічних цілей [3, с. 78]: повністю забезпечити потреби розвитку сільського господарства в інвестиційних ресурсах; забезпечити зростання інвестиційних можливостей сільськогосподарських товаровиробників; розширити фінансування сільського господарства задля підвищення його інвестиційної привабливості.

1. Державний комітет статистики України // [Електронний ресурс]. Режим доступу: http://www.ukrstat.gov.ua

2. Статистичний збірник «Сільське господарство України» за 2017 рік. - Київ: Державна служба статистики України, 2018. - 245 с.

3. Стратегічні напрями розвитку сільського господарства України на період до 2020 року /за ред. Ю.О. Лупенка, В.Я. Месель-Веселяка. - К.: ННЦ «IAE», 2012. - $182 \mathrm{c}$. 